\title{
COMMUNITY EMPOWERMENT IN THE CONTEXT OF IMPLEMENTING SMOKING FREE AREA
}

\author{
${ }^{1}$ Vina Yulia A, ${ }^{2}$ Fauzie Rahman, ${ }^{2}$ Nur Laily, ${ }^{2}$ Ayu RS, ${ }^{3}$ Atikah R, ${ }^{3}$ Fahrini YS, ${ }^{3}$ Lia A, \\ ${ }^{4}$ Meitria SN, ${ }^{4}$ Andini OP, ${ }^{5}$ Dian R, ${ }^{6}$ Agus MR, ${ }^{6}$ Yolanda AM, ${ }^{6}$ Widya WR., ${ }^{6}$ Sri Indang K., \\ ${ }^{6}$ Misda Silva., ${ }^{6}$ Nanda SP., ${ }^{7}$ Syifaul Husna \\ (anharvinayulia@gmail.com)
}

Public Health Program Study, Medical Faculty, Lambung Mangkurat University Jl. A Yani km. 36, Banjarbaru, South Kalimantan, $70714^{1-7}$

\begin{abstract}
The survey results of the Field Study Experience of Students in the Public Health Study Program in 2018 showed that the number of smokers in Sungai Alang Village was the highest compared to other villages in Karang Intan Subdistrict, which was $84.4 \%$. Based on these problems, health promotion is needed to help improve knowledge, attitudes and changes in smoking behavior in the community. This research using operational research methods. The study began with the formulation of an innovative and creative experiment by developing a smoke-free area program. This program has been carried out in several places, namely, health education, smoking supervisors in households, construction of cigarette corners and appointment of antismoking cadres, consultation on smoking arrangements, and the establishment and declaration of a smoke-free area. The sample size was 30 respondents. Data were analyzed using descriptive statistics. Increased knowledge of the community about the dangers of smoking and prevention efforts that must be done, the formation of families committed to supervise family members who smoke, cigarette corners as a pilot built and added health promotion media containing efforts to prevent smoking and the dangers and effects of smoking in body. Cigarette corners that have been made into a gathering place for smokers to reduce the number of smokers in the house, and make a declaration of smoke-free areas by the community together with village officials. Establishment of Committed Families and Anti-smoking Supervisor Cadres through Regulations of Village Heads. For sustainability, hopefully cadres and community leaders socializing the smoke free area rules routinely, and impose sanctions for violators.
\end{abstract}

Keywords: cigarette, community empowerment, non-smoking area, public health, smoking limited area

\section{Introduction}

WHO data shows that around 1.1 billion smokers in the world, a third of whom come from the group aged 15 years and over. Meanwhile, the prevalence of smokers in Indonesia in the population above the age of 10 years is 27.7\% [1]. Based on Basic Health Research Data (2018), 9.1\% of the population aged 10-18 years are active smokers. Then the smoking behavior of the population 15 years and over has not yet decreased from 2016 tended to increase from $32.8 \%$ to $33.8 \%$ in 2018 . The results of Basic Health Research Data (2018), 
showed that smokers in South Kalimantan Province aged $\geq 10$ years were $23,5 \%$ [2]. Data from the Banjar District Health Office shows that $77.9 \%$ of smokers in the Banjar District smoke in the house with household members [3]. Based on the data from the diagnosis results of the Community Field Study Experience of the Student Public Health Study Program in 2018 in Sungai Alang Village which is one of the villages along the river flow, shows that the number of smokers who smoke in the house with family members is the highest compared to 17 villages the other was in Karang Intan Subdistrict, which was 84.4\% [4].

The problem of smoking behavior in Sungai Alang Village community is difficult to be eliminated, especially in active smokers who have been addicted for years. Cigarette addiction is not only experienced by parents, but even at the age of adolescents, some people have started to become addicted to cigarettes. Initially just wanted to try because seeing friends around finally got addicted and started buying it myself. The average cigarette consumed by one to two packs a day. The smoking behavior of parents is feared that it can affect the behavior of their children who ultimately follow the behavior of their parents. Sungai Alang village has the most smokers compared to other villages in the Karang Intan sub-district, which is $84.4 \%$. In addition, ARI is the seventh most common disease in the Karang Intan 2 Puskesmas work area [4].

The results of the risk factor analysis from the Field Study Experience of the Student Public Health Study Program in 2018 in Sungai Alang Village were many smoking behaviors inside the house are caused by the lack of education about smoking, the absence of smoking areas outside the home, and the absence of a smoking ban policy from village. This is supported by public opinion obtained from the results of focus group discussions (FGD) that:

"The problem of smoking is indeed difficult to overcome or eliminate. The lack of counseling about the dangers of smoking in the house, and the minimum prohibition when I smoke in the house both my wife and my child so that I feel free to smoke in the house".

Therefore, intervention is needed in the form of health education for active smokers as well as the family and community environment, through the establishment of a community empowerment role model that can reduce the number of smokers and the formation of smoking-restricted areas in Sungai Alang Village [4].

\section{Methods}

This research using descriptive analytic method The study began with the formulation of an innovative and creative experiment by developing a smoke-free area program. This program has been carried out in several places, namely, health education, smoking supervisors in households, construction of cigarette corners and appointment of anti-smoking cadres, consultation on smoking arrangements, and the establishment and declaration of a smoke-free area. The sample size is 30 respondents.

Data were analyzed using descriptive statistics. To see an overview of the main characteristics and independent variable (knowledge level based on monitoring and evaluation for $1^{\text {st }}$ until $3^{\text {th }}$ months). Univariate analysis of categorical data was carried out by presenting numbers and percentages. Furthermore, bivariate analysis was performed using the Wilcoxon test to examine the difference knowledge before and after the intervention. 


\section{Results}

Following are the results of an evaluation of knowledge before and after the intervention of providing education and training of Anti-Smoking cadres:

Table 1. Distribution Frequency of Evaluation of Knowledge Level Before \& After the Intervention of Providing Education \& Training of Anti-Smoking Cadres

\begin{tabular}{clcc}
\hline No. & Knowledge level & Before intervention (\%) & After intervention (\%) \\
\hline 1. & Good & $0(0 \%)$ & $30(100 \%)$ \\
2. & Enough & $6(20 \%)$ & $0(0 \%)$ \\
3. & Less & $24(80 \%)$ & $0(0 \%)$ \\
& Total & $\mathbf{1 0 0 \%}$ & $\mathbf{1 0 0 \%}$ \\
\hline
\end{tabular}

Based on table 1, it can be seen that the level of knowledge of participants before counseling and training is good knowledge of 0 people $(0 \%)$ and with enough knowledge of 6 people $(20 \%)$ and less knowledge of 24 people $(80 \%)$. However, after being given counseling and training, the knowledge of all participants improved to 30 people (100\%).

Evaluation of outputs conducted on the results of educational activities is to conduct an assessment of knowledge for 3 months contained in the following table:.

Table 2. Distribution Frequency of Knowledge Level Based on Monitoring \& Evaluation from $1^{\text {st }}$ Month to $3^{\text {rd }}$ Month

\begin{tabular}{clcccccc}
\hline \multirow{2}{*}{ No. } & \multirow{2}{*}{$\begin{array}{c}\text { Knowledge } \\
\text { level }\end{array}$} & \multicolumn{2}{c}{$\mathbf{1}^{\text {st }}$ Month } & \multicolumn{2}{c}{$\mathbf{2}^{\text {nd }}$ Month } & \multicolumn{2}{c}{$\mathbf{3}^{\text {rd }}$ Month } \\
\cline { 2 - 7 } & $\mathbf{N}$ & $\mathbf{\%}$ & $\mathbf{N}$ & $\mathbf{\%}$ & $\mathbf{N}$ & $\%$ \\
\hline $\mathbf{1 .}$ & Good & 5 & $16.7 \%$ & 6 & $20 \%$ & 7 & $23.3 \%$ \\
2. & Enough & 22 & $73.3 \%$ & 21 & $70 \%$ & 21 & $70 \%$ \\
3. & Less & 3 & $10 \%$ & 3 & $10 \%$ & 2 & $6.7 \%$ \\
& Total & $\mathbf{1 0 0 \%}$ & $\mathbf{1 0 0 \%}$ & $\mathbf{1 0 0 \%}$ & $\mathbf{1 0 0 \%}$ & $\mathbf{1 0 0 \%}$ & $\mathbf{1 0 0 \%}$ \\
\hline
\end{tabular}

Based on table 2 it can be seen that the level of knowledge of participants in monitoring and evaluation in the first month is good knowledge of 5 people $(16.7 \%)$, quite as many as 22 people $(73.3 \%)$, and less as many as 3 people $(10 \%)$. The level of knowledge of participants in monitoring and evaluation in the second month was good knowledge of 6 people $(20 \%)$, quite a total of 21 people $(70 \%)$, and less than 3 people $(10 \%)$. While the level of knowledge of participants in monitoring and evaluation in the third month was good knowledge of 7 people $(23.3 \%)$, quite a total of 21 people $(70 \%)$, and less than 2 people $(6.7 \%)$.

The following differences in the level of knowledge before and after intervention using Wilcoxon test. 
Table 3. Differences in Knowledge Levels Before and After Intervention

Test Statistics ${ }^{a}$

\begin{tabular}{|l|r|}
\hline & \multicolumn{2}{|c|}{ post-pre } \\
\hline Z & $-3.631^{\mathrm{b}}$ \\
Asymp. Sig. (2-tailed) & .000 \\
\hline
\end{tabular}

a. Wilcoxon Signed Ranks Test

b. Based on negative ranks.

Based on the Wilcoxon test results, it is known that the value of sig. $0.0001<0.05$ which means the decision is Ho rejected, meaning that there was a significant difference in knowledge between before and after the counseling intervention and anti-smoking cadre training.

Qualitative evaluation was carried out after 3 months of monitoring and evaluation using pre-post tests at the end of each month. Interviews were conducted with village heads, village midwives and community leaders in Sungai Alang Village. The purpose of the interview conducted is to find out more deeply about the benefits of implementation and the effectiveness of intervention activities. The following is an interview excerpt from the informant.

"... Very useful, so this is because the majority of Sungai Alang villagers are smokers, with interventions carried out we can see from the small scale first, from the village office environment. At the village office they have now started to reduce smoking, then those who usually smoke in the house now have started to stop doing it, even though not all of them have done it ... With a cigarette corner in every household is very beneficial for people who smokers to reduce smoking in the house..." (Village Head

"... the information provided is beneficial for the residents of Sungai Alang so that they know the dangers and effects of smoking so that they can reduce it ..." (Village

Midwife)

"... it is very useful and it is also a health recommendation for the community. So the benefits are very big and help people to live healthy. In addition, the benefits are felt not only for yourself but also other people also feel it ... The activity of delivering messages about the dangers of smoking in Sungai Alang Village and the existence of a smoking corner in every household is very beneficial for the community of Sungai Alang Village ..." (Community Leader)

Based on the results of the interview, Sungai Alang Village community, especially the Village Head, Village Midwives and Community Leaders stated that the activities carried out benefited the villagers. This was consistent with the results of the following interview excerpt.

"... the management of intervention facilities carried out by the community, especially the Sungai Alang village apparatus regarding the maintenance of intervention facilities, the Sungai Alang Village community will work together to maintain and care for the smoking corner in each household ..." 
Based on interviews with community leader in Sungai Alang Village, it is known that counseling activities by cadres is a good method to reduce smokers in Sungai Alang Village who smoke improperly, because passive smokers are more dangerous than active smokers. Cadres carry out their duties properly and in accordance with the responsibilities given. This is consistent with the results of the following interview excerpt.

"... with the cadres participating in the training and carrying out their duties properly when delivering counseling material in the corner of the cigarette, the cadres performed their duties well and were well received by the community because the cadres did come from the Sungai Alang community itself .." (Community Leader)

Based on the results of interviews, it is known that all cadres who have been appointed will show commitment in carrying out their duties as cigarette cadres in Sungai Alang Village. The implementation of these activities can be done with a strategic approach to empowering health cadres in the community through the introduction of the use of health information systems to cadres, because currently health cadres as partners of health workers really need capacity building in accordance with technological developments in the current digital era. The development of the current information system is very important and determining what can be used by health cadres to improve the ability to monitor the development of public health [7]. The statement is in accordance with the following interview excerpt:

"... we as cadres here will continue to monitor the course of this activity. Hopefully it can continue ..." (Health Cadre)

"... for the intervention I think is enough because remembering this method does not directly reprimand others but self-awareness not to smoke in the house ..." (Head of Sungai Alang Village)

The role of cadres in carrying out their duties as providers of health information has a major influence on behavior in the community [9]. The statement is in accordance with the interview excerpts with the following informants:

"... God willing, we as cadres here will continue to monitor the course of this activity. Hopefully it can continue ... "(Community Leader)

A total ban on smoking is more likely to make the smoker reduce or even stop his habit, compared to if the ban only applies in some rooms. Total ban at home is more effective in reducing the number of smokers among women and elderly people over 65 years and stopping smoking in homes without children. The prohibition of smoking at home is actually not forcing smokers to quit, but rather protecting women and children, especially pregnant women from the adverse effects of their husbands' cigarettes, so that the number of passive smokers decreases, besides the prohibition of smoking at home can reduce adolescents who try to smoke [10]. The statement is in accordance with the interview excerpts with the following informants:

"... It is said to be able to overcome yes able to overcome. But yes, as stated. If it's not significant yet, it still needs time. If we solve the problem, if I think there has been an effort to go there, but it still cannot be maximized, because we know 
the number of our society, then we are moving here plus cadres, but the work of the cadres is not only as cadres but they also have other responsibilities that must be carried out. But to overcome the problem I think it's good and I think there will be significant changes later ... "(Head of Sungai Alang Village)

"... Clearly reducing and yes it's impossible to delete it. Yes at least reduce it. Because all of that also needs a process ... "(Community Leader)

Sungai Alang villagers assume that if someone immediately reprimands someone who smokes, then there will be a sense of discomfort and the person who is reprimanded will most likely have a sense of resentment in his heart. Therefore, through this activity, it has an impact on the ease of interaction between smokers and smoker's supervisory officers.

\section{Discussions}

Based on the qualitative result it can be concluded that the activities carried out provide benefits to the village community. Educational activities undertaken can reduce the number of people who smoke in homes and places that have smoking bans. People finally come out of the house to smoke and look for a place that is used as a corner of cigarettes. In addition, the public also knows about the dangers and effects of smoking so they try to reduce cigarette consumption. With the results of this activity, it was expected that the commitment to the establishment of a non-smoking zone will run smoothly. A non-smoking area is a room or area that is declared prohibited from engaging in smoking, or producing, selling, advertising, promoting and or promoting tobacco products. Regulations regarding the determination of non-smoking areas are issued by the government through Government Regulation No. 19 of 2003 concerning the safeguarding of cigarettes for health which briefly explained the content of hazardous substances contained in cigarettes, the implementation of safeguarding cigarettes and the role of the community in the effort to safeguard cigarettes for health [5].

Education is one of the health education activities that can affect the way a person views himself and his environment, which is intended to develop or enhance certain abilities. Based on this statement, it can be concluded that the education that has been carried out in Sungai Alang Village affects the community's perspective, so the better one's perception of the health information delivered.

Evaluate the output of the formation of the cigarette corner which was equipped with the installation of supporting media such as posters, banners, leaflets and booklets of cigarette corners at the patrol posts in each household. The output of the formation of the cigarette corner was the increasing community participation in utilizing the cigarette corner as a smoking area outside the home. The cigarette corner was designed to be a place that serves as an educational platform for behavior change that is carried out through the dissemination of information, communication, motivation, and education both verbally, in writing, and in demonstrations to the target group so that the same understanding, knowledge, and willingness to participate active in welfare development.

Management of intervention facilities undertaken by the community against interventions in Sungai Alang Village is one part of the efforts of the village community in collaboration with the Implementation Team for the development of a Non Smoking Area including situation analysis, the formation of committees or working groups on policy making, policy 
making, infrastructure preparation, dissemination of Non Smoking Area implementation, Non Smoking Area implementation, supervision and law enforcement as well as monitoring and evaluation [6].

The establishment of the cigarette corner has been classified as very good, because this method is an indirect method and is assessed by the Sungai Alang Village community as a pretty good way to awaken the Sungai Alang village community not to smoke inside the house. The management of facilities and infrastructure that have been provided at the cigarette corner will be borne by the Sungai Alang Village community and will be directly coordinated by the Sungai Alang Village Head to each household environment in order to maintain and manage the cigarette corner well.

The formation of the cigarette corner is accompanied by training of health cadres. All designated cadres will show their commitment in carrying out their duties as cadres in Sungai Alang Village. Cadre is the spearhead in the socialization to the community. A health cadre is someone chosen by the community and has the duty to improve community health voluntarily. The health education provided is related to the problems currently faced by the community, so it can be concluded that the cadre is a source of reference for community referrals, trusted by the community and has a close relationship with the community because the cadres are part of the community.

The making of cigarette corners and educational activities have an impact on reducing the number of smokers in the house, although it does not eliminate $100 \%$ of smokers in Sungai Alang Village. Reducing the number of smokers who smoke in their homes in Sungai Alang Village is a benefit of increasing smoker's knowledge of the effects of smoking inside the home, so that smokers are aware not to have a health impact on their families.

\section{Conclusions}

There was a significant difference in knowledge between before and after the counseling intervention and anti-smoking cadre training. the activities carried out provide benefits to the village community. Educational activities undertaken can reduce the number of people who smoke in homes and places that have smoking bans. The establishment of a cigarette corner which was complemented by the installation of supporting media such as posters, banners, leaflets and booklets of cigarette corners at the patrol posts in each household increases community participation in using the cigarette corner as a smoking area outside the home. The appointed cadres will show their commitment in carrying out their duties as cigarette cadres in Sungai Alang Village and carry out their duties properly so that it has an impact on the ease of interaction between smokers and smoker's supervisory officers.

\section{References}

[1] Lorensia A, Yudiarso A, Herwansyah FR. Perception, Effectiveness and Safety of the Use of Electric Cigarettes (E-CIGARETTE) by Active Smokers as Therapy in Smoking Cessation: Mixed Methods with Quantitative and Qualitative Study Approaches. Journal of Tropical Pharmacy And Chemistry 2017; 4(2): 66-78.

[2] Basic Health Reserach Report 2018. Ministry of Health Republic of Indonesia Health Research and Development Agency. 2018

[3] Banjar District Health Office. Health Program Report. 2019 
[4] Ridwan, MR, et al. Report on the Implementation of Student Field Learning Experiences. Public Health Study Program, Faculty of Medicine, Lambung Mangkurat University. 2018

[5] Fatonah S, Amatiria G. Citizens Compliance with No Smoking Area Regulations in South Lampung. Nursing Journal 2016; 12(01): 149-154.

[6] Muliku H S, Polii B, Kumurur V. Analysis of Non-Smoking Area Development in Robert Wolter Mongsidi Hospital (Level III) Manado. Community Health 2017; 02(01): 13-29.

[7] Damayanti A. The Use of Electric Cigarettes in Surabaya's Personal Vaporizer Community. Periodical Journal of Epidemiology 2016; 4(2): 250-261.

[8] Jamaluddin $\mathrm{Y}$ et al. Analysis of the Impact of Village Fund Management and Use on Regional Development. Journal of Government Science and Social Politics UMA 2018; 6(1): 14-24.

[9] Rahayu L, et al. RIAS "Remaja Siaga Asap Rokok" (Teenage Cigarette Smoke Alert) Program: Preventing and Overcoming Cigarette Addiction. MKK Journal 2018; 1(1): 79-89.

[10] Ramadhan K. Relationship of Prohibition of Smoking at Home with the Success of Quitting Smoking. Profesi Medika Journal 2017; 11(1): 1-8. 